\title{
Milk coagulation properties and methods of detection
}

\author{
Simone Beux ${ }^{1 *}$ Edimir Andrade Pereira $^{2}$ Martino Cassandro ${ }^{3}$ \\ Alessandro Nogueira ${ }^{4}$ Nina Waszczynskyj ${ }^{1}$ \\ ${ }^{1}$ Departamento de Engenharia Química, Universidade Federal do Paraná (UFPR), 81531-980, Curitiba, PR, Brasil. E-mail: beuxsimone@gmail.com. \\ ${ }^{*}$ Corresponding author. \\ ${ }^{2}$ Departamento de Química, Universidade Tecnológica Federal do Paraná (UTFPR), Pato Branco, PR, Brasil. \\ ${ }^{3}$ Departamento de Ciências Animais, Universidade de Padova, Agripolis, Legnaro, Italy. \\ ${ }^{4}$ Departamento de Engenharia de Alimentos, Universidade Estadual de Ponta Grossa (UEPG), Ponta Grossa, PR, Brasil.
}

ABSTRACT: One of the most crucial steps in cheesemaking is the coagulation process, and knowledge of the parameters involved in the clotting process plays an important technological role in the dairy industry. Milk of different ruminant species vary in terms of their coagulation capacities because they are influenced by the milk composition and mainly by the milk protein genetic variants. The milk coagulation capacity can be measured by means of mechanical and/or optical devices, such as Lactodynamographic Analysis and NearInfrared and Mid-Infrared Spectroscopy.

Key words: clotting, curd firmness, lactodynamograph, infrared spectroscopy.

Propriedades de coagulação do leite e métodos de detecção

RESUMO: Uma das etapas mais importantes na fabricação de queijos é o processo de coagulação. O conhecimento dos parâmetros envolvidos nesse processo desempenha um papel tecnológico importante para a indústria de laticinios. O leite de diferentes espécies de ruminantes varia em termos de capacidade de coagulação, pois são influenciados pela composição e principalmente pelas variantes genéticas da caseína. Estas características podem ser avaliadas por meio de dispositivos mecânicos elou ópticos, tais como, a Análise Lactodinamográfica e a Espectroscopia de Reflectância do Visível ao Infravermelho Próximo (NIR) e Médio (MIR).

Palavras-chave: coagulação, firmeza da coalhada, lactodinamógrafo, espectroscopia no infravermelho.

\section{INTRODUCTION}

The global scenario for the dairy chain and specifically for cheese is favorable. According to PENASA et al. (2015) the European Union produces about half of the world cheese and is the main international supplier and according to OECD-FAO (2013), the demand for global cheese imports will increase significantly, by $20 \%$ through 2022 . For the dairy industry it is critical to know milk coagulation properties, once they define technological aspects of production. Milks with favorable characteristics for cheese production must present short clotting time and curd firmness, resulting in products with desirable composition and these requirements are important for processing (CASSANDRO et al., 2008). Several factors have influenced on Milk Coagulation
Properties (MCP), such as, nature and concentration of coagulating enzyme, milk temperature, titratable acidity (TA), protein (casein and its fractions), calcium and phosphorus contents and somatic cell count (SUMMER et al., 2002). Among the factors cited, total casein content and its genetic variants, as well as, titratable acidity are the ones that seem to have greater influence on MCP. The қ-casein (қ-CN) and $\beta$-casein $\mathrm{B}(\beta-\mathrm{CN} \mathrm{B})$ are associated with positive effects on micelles stability and curd reactivity resulting in a shorter clotting time thus producing a more consistent curd (MARIANI et al., 2002), and the titratable acidity is involved in the aggregation rate of casein micelles, in curd reactivity and in the syneresis rate (FORMAGGIONI et al., 2001). So, the determination of the MCP is extremely important, since raw milk from cows, buffalo, sheep or goats (of 
the same or different breeds) has different coagulation capacities (ABEYKOON et al., 2016), that is, the milk composition is not the same. This ability can be determined using mechanical devices like Reomether, Coagulometer, Lactodynamograph and more recently optical devices such as the Optigraphs (NearInfrared and Mid-Infrared). These measurements are traditionally expressed using the rennet coagulation time (r, min), time ( $\mathrm{min}$ ) to curd firmness (CF) to reach $20 \mathrm{~mm}(\mathrm{k} 20)$, and $\mathrm{CF}$ in $30 \mathrm{~min}$ after enzyme addition (a30, mm) (ANNIBALDI et al., 1977). BITTANTE et al. (2013) showed the model CF as a function of time ( $\mathrm{CFt} \mathrm{mm}$ ) over a 30min interval; the model offers very good fitted data obtained from milk samples different in composition. More recently, Mid Infrared (MIR) Spectroscopy, more precisely Fourier Transform (FTIR), has been reported as an indirect method, using less time and lower costs for analysis (BONFATTI et al., 2011b; DE MARCHI et al. 2013). The aim of this review is to provide a brief overview on MCP determination methods (Lactodynamograph and Infrared Spectroscopy) and highlight the main factors influencing milk coagulation.

\section{Milk coagulation properties (MCP)}

In general, MCP may be defined as the ability of milk to react with a coagulant (cheesemaking) and to form a curd with proper consistency and in optimal time for processing, as well as present good ability for syneresis. Coagulant reacts directly with casein that constitutes the main component to produce cheese and from which depends great part of the rheological characteristics of the curd, mass reduction ability and milk transforming efficiency (CASSANDRO et al., 2008). Milk coagulation is influenced by factors such as chemical composition, milk acidity, somatic cells count, as well as the coagulating enzyme source and concentration (IKONEN et al., 2004) suggesting that technological properties come from hereditary characteristics and it can be enhanced by genetic improvement. According to IKONEN et al. (2004) and CASSANDRO et al. (2008) yield in cheese production depends on MCP and can vary greatly from one cow to another, with $30 \%$ to $40 \%$ of this variation due to genetic differences. MCP may be expressed by combining the time between rennet addition and the onset of milk coagulation ( $\mathrm{r}$, min), time necessary for the curd to reach a $20 \mathrm{~mm}$ firmness $(\mathrm{k} 20$, min) and curd firmness at the end of analysis (a30, mm). These characteristics can be registered by usage of alternative systems based on optical, thermal, mechanical and vibrational methods, which have been thoroughly reviewed by O'CALLAGHAN et al. (2002).
Two important factors affecting MCP: proteins and titratable acidity

Proteins: During the last decades, breeding for dairy cattle has been focused on $\mathrm{kg}$ of milk protein, but the total protein content appears to be a poor indicator of MCP. In a study by IKONEN et al. (2004), neither the total content of protein nor milk casein were considered suitable for the implementation of an indirect selection to improve MCP. Bovine milk contains about $3 \%$ protein, which can be classified into two major groups: caseins, which account for about $80 \%$ and $20 \%$ whey proteins. Milk casein is essential in cheeses processing because they form a gel network, which retains other constituents of milk which form the cheese. Casein $(\mathrm{CN})$, a phosphoprotein characterized by acids clusters and stabilized by calcium ions and phosphate, is comprised of: $\alpha_{\mathrm{S} 1}-\mathrm{CN}, \alpha_{\mathrm{S} 2}-\mathrm{CN}, \beta-\mathrm{CN}$ and қ-CN in approximate proportions of 4:1:4:1 (BONIZZI et al., 2009). Proteins present in whey include in particular $\alpha$-lactalbumin $(\alpha$-La) and $\beta$-lactoglobulin $(\beta-\mathrm{Lg})$ at the approximate ratio of $1: 3$, together with serum albumin (BSA) and immunoglobulins (Igs) as minor constituents. For $\mathrm{CN}, \beta-\mathrm{Lg}$ and $\alpha$-La over 60 genetic variants have been identified (FARRELL et al., 2004). Genetic variants of CNs and of the whey proteins affect many properties that are crucial in the coagulation process (BONFATTI et al., 2008). Casein polymorphisms have been known as factors affecting milk composition, both because of its qualitative changes, related to mutations in a single gene, as due to its quantitative variation, differences in the expression of alleles involved in milk protein synthesis (MAYER et al., 1997). The genetic factors have a direct influence on milk coagulation, as described by HALLÉN et al. (2008) the B alleles of both $\kappa-\mathrm{CN}$ and $\beta-\mathrm{CN}$ contribute positively and the $\kappa-\mathrm{CN} \mathrm{A}$ and $\mathrm{E}$ alleles are associated with poor or not coagulation properties. Thus, not only the concentration of total protein and casein are sufficient to establish MCP. Identifying polymorphic genes encoding the key milk proteins can aid in a better understanding of milk clotting process; particularly the genetic variants of қ- $\mathrm{CN}$ and its fractions and of $\beta-\mathrm{Lg}$ influence on milk composition and/or technological behavior (PATERSON et al., 1999). According to MARIANI et al. (2002), milks which have higher қ-CN $\mathrm{B}$ content have better reactivity with rennet, better clot forming ability, thus resulting in higher yield. KÜBARSEPP et al. (2005b) reported that all measures related to the MCP of bovine milk were significantly better for genotype B of қ-CN and worse for қ-CN A and yet қ-CN B also exhibited the lowest percentage of milk samples that do not coagulated (NC). The қ-CN allele B, for example, has been associated with 
increased concentration of қ- $\mathrm{CN}$ in milk compared to the allele A (GRAML \& PIRCHNER, 2003) and also with a higher proportion of the total protein and $\mathrm{CN}$. This characteristic regarding the қ-CN B variant, according to DI STASIO \& MARIANI (2000) is related to a higher content in қ-CN in absolute and relative terms, which implies the presence of micelles with a lower average diameter, and smaller micelles have greater reactivity with the enzyme with the highest curd formation rate reflecting favorably on the rheological characteristics. PENASA et al. (2010) evaluated the influence of genotypes of $қ-\mathrm{CN}$ and $\beta-\mathrm{CN}$ in milk from Holstein cows on MCP and also reported a notable influence on this parameter. Another relationship in genetic terms refers to the increase in the total қ- $\mathrm{CN}$ content or the relative proportion between қ- $\mathrm{CN}$ and the total levels of casein, which decreases the amount of $\alpha_{\mathrm{S} 1}$ - and $\alpha_{\mathrm{S} 2}-\mathrm{CN}$ and $\mathrm{pH}$, which has a positive effect on MCP (BONFATTI et al., 2011a). Whey proteins also influence indirectly the MCP results. Milks having a higher content of $\beta-\operatorname{Lg} B$, have smaller amount of whey proteins, but at the same time are richer in casein, $0.12 \%$ more, difference when compared to milks with the greatest presence of $\beta-\mathrm{Lg}$ A (MARIANI, 1999). HILL (1993) studied the relationship between genotypes of $\beta-\mathrm{Lg}$ in milk composition in New Zealand and according to the results, milk of cows with AA genotype for $\beta$-Lg showed 28\% more whey protein, $7 \%$ less casein, $11 \%$ more fat and $6 \%$ less total solids when compared to milk of BB genotype cows. SUMMER et al. (2002) reported the influence of $\beta$-Lg genetic types is remarkable, they studied the milk of Modaneses cows and observed that cows with $\beta$-Lg type A have a milk with higher content of whey proteins while cows with $\beta$-Lg type B produced a milk on average richer in casein with significant effects on productivity, particularly related to cheese. JENSEN et al. (2012) observed in milks with good MCP the prevalence of the variant $\mathrm{B}$ for $\beta-\mathrm{Lg}$ as well as for $\beta-\mathrm{CN}$ and қ-CN proteins.

Titratable acidity (TA): Titratable acidity has an essential role in all milk clotting phases that includes the aggregation rate of para-casein micelles, rennet activity and syneresis rate (SUMMER et al., 2002). In the production of premium cheeses, for example, low acidity milks are considered unsuitable because of their negative effects on enzymatic coagulation and on final rheological properties of the cheese (FORMAGGIONI et al., 2001). A progressive lowering in acidity corresponds to an increase in the frequency of milks with low reactivity to the clotting enzyme (MARIANI et al., 2002). Milks with low acidity have a greater $r$ (min) value and take longer to reach gel firmness (NÁJERA et al., 2003).
FORMAGGIONI et al. (2001) obtained better answer to the three parameters that determine MCP from milk with average acidity of $15.7 \pm 0.30^{\circ} \mathrm{D}$ : $\mathrm{r}=16.3 \pm 2.3 \mathrm{~min}$; $\mathrm{k} 20=9$, $1 \pm 2.0 \mathrm{~min}$ and $\mathrm{a} 30=27.1 \pm 5.3 \mathrm{~mm}$; followed by milk with $14.4 \pm 0.12{ }^{\circ} \mathrm{D}$ : $\mathrm{r}=19.1 \pm 1.6 \mathrm{~min} ; \mathrm{k} 20=10.8 \pm 1.7 \mathrm{~min}$ and $\mathrm{a} 30=21.1 \pm 3.6 \mathrm{~mm}$ and for milk with lower acidity $13.1 \pm 0.18{ }^{\circ} \mathrm{D}: \mathrm{r}=22.1 \pm 3.5 \mathrm{~min} ; \mathrm{k} 20=13.2 \pm 4.9 \mathrm{~min}$ and a30 $=14.5 \pm 7.0 \mathrm{~mm}$. Slightly acidic milks respond better to the coagulation process as a function of reduction in the electrostatic repulsion of micelles and flocculation with a lesser degree of қ-CN hydrolysis (WALSTRA, 1993).

Milk coagulation determination methods Lactodynamographic parameters (LAT)

The MCP are traditionally measured with a Lactodynamograph. Equipment available for this analysis are: (1) Latodinamografo ${ }^{\circledR}$ (LAT; Foss-Italy), which replaced the Formagraph ${ }^{\circledR}$ (Foss Electric, Denmark) and the (2) Computerized Renneting Meter $\left(\mathrm{CRM}^{\circledR}\right)$ from Polo Trade, Italy (ANNIBALDI et al., 1977; ZANNONI \& ANNIBALDI, 1981; DADOUSIS et al., 2016). The method of determining the MCP by lactodynamographic parameters has been classified as a mechanical or rheological system (O'CALLAGHAN et al., 2002) and is based on oscillation recording, which is driven by an electromagnetic field created by the oscillation of a small stainless steel pendulum immersed in the milk sample. The equipment has the capacity to simultaneously analyze ten samples. The system records physical and chemical changes that occur in milk during the coagulation process, when the enzyme hydrolyzes the қ-casein and induces changes in the viscosity and elasticity of milk. During the analysis, milk temperature is kept constant $\left(35^{\circ} \mathrm{C}\right)$ and the device then measures the small forces that act on the pendulum during coagulation (gelation) when they oscillated in a linear manner, and the greater the coagulation intensity, the smaller the pendulum swings. The detected signal is amplified and registered, then generating diagrams shaped as "bells" or "champagne flutes" called lactodinamogram expressed in gel firmness versus clotting time (O'CALLAGHAN et al., 2002). The Formagraph ${ }^{\circledR}$ equipment includes devices that record the width (mm) of the graph during testing, every 15 seconds (CIPOLAT et al., 2012); however, the new equipment, Lattodinamografo $\mathrm{V} 2^{\circledR}$, is more efficient registering a signal every 7.5 seconds. As can be seen in Figure 1a, three parameters are considered (ANNIBALDI et al., 1977): r (rennet coagulation time) - represents the time for the beginning of enzymatic coagulation in minutes and concerning the time interval between rennet addition and the onset of clotting (the instrument detects a change in viscosity); $\mathrm{k} 20$ - time required in minutes for the gel to 
reach a consistency with an amplitude of $20 \mathrm{~mm}$. It is an inversely proportional rate to the aggregation speed of casein micelles in the secondary stage of enzymatic coagulation and a30 - curd firmness or consistency which is determined in millimeters $(\mathrm{mm})$ and corresponds to the diagram wideness obtained 30 minutes after coagulant addition. Regarding clot firmness a30 is the pattern testing time, but it is possible to perform the analysis in 45 (a45) or 60 (a60) minutes. According to ZANNONI \& ANNIBALDI (1981) milk is regarded as excellent with respect to its MCP when it presents an " $r$ " from $11 \mathrm{~min}$ and $30 \mathrm{sec}$ through $18 \mathrm{~min}$, a " $\mathrm{k} 20$ " between $5 \mathrm{~min}$ and $30 \mathrm{sec}$ and $8 \mathrm{~min}$ and $30 \mathrm{sec}$ and an "a 30" from 20 to $40 \mathrm{~mm}$. However, as milk chemical composition is variable different shapes of curves (Figure 1b) have been recognized and used as a reference.

Each diagram shown infigure $1 \mathrm{~b}$ corresponds to milks with defined properties as: Type A: milk with excellent coagulation characteristic; Type B: milk with slow coagulation but with good clot formation speed and with relatively high final consistency (typical of cattle in late lactation and rich in casein); Type C: first phase with fast coagulation time, followed by a decrease in the speed of clot formation with a discrete final curd consistency (occurs in cattle milk in early lactation and low-casein); Type D: clotting phase develops very fast and curd achieves a high consistency (milk slightly acid and/or rich in casein); Type E: has long coagulation time and low final curd consistency (high content of somatic cells); Type F: has an extremely long time for the start of coagulation and weak final curd consistency (high somatic cell count and $\mathrm{pH}$ ), Type DD: features characteristic similar to milk "Type D", but in a more intense way (often reported in acid or old milk); Type FF: milk which does not coagulates (in 30min of analysis time). Combination of the three parameters $\mathrm{r}, \mathrm{k} 20$ and $\mathrm{a} 30$ are used for classifying milk as excellent (A), good (B, C and D), defective (E, F, $\mathrm{DD})$ and no coagulating (FF). All measurements are automatically performed and raw data are stored in the memory of a computer coupled with the equipment, which analyzes the data so the traditional MCP results and lactodynamographic curve can be obtained (BITTANTE et al., 2012). PENASA et al. (2015) considering the traditional measures, $\mathrm{r}(\mathrm{RCT})$ and $\mathrm{a} 30$ values, as two separate traits, they combined both, to form a milk clotting ability index (IAC):

$I A C=100+\left(a_{30}-\right.$ mean $\left._{a_{30}}\right) / S D_{a_{30}} * 2.5-\left(R C T-\right.$ mean $\left._{R C T}\right) / S D_{\text {RCT }} * 2.5$

According to authors besides the MCP traditional result, the IAC was created and introduced as a new feature to synthesize $\mathrm{r}$ and $\mathrm{a} 30$ values, giving the same importance $(50 \%)$ for these features in the index, which can be changed according to different applications and/or cheese production. Traditional method also has some limitations as the existence of non-coagulant samples (NC) in 30min of analysis and problems in obtaining $\mathrm{k} 20$ values and its repeatability and the nature of the information yielded by a30 values (IKONEN et al., 2004; BITTANTE, 2011). The k20 has practical importance because it is considered the ideal time indicator for curd cutting and; therefore, is related to product yield and its quality (BYNUM \& OLSON, 1982). The a30 value is often dependent on $r$ ( $\mathrm{min})$, both phenotypically and genetically, becoming evident that the longer the coagulation time, the shorter the available time interval for curd hardening thus resulting in a lower final firmness (IKONEN et al., 2004). According to BITTANTE (2011) to overcome these limitations new technologies and the use of more information provided by traditional analysis should be explored. Hence, the objective of his research was to exploit all available information by appropriately modeling the curd-firming process over time $(\mathrm{CFt})$ using data measured by $\mathrm{CRM}^{\circledR}$. So the author applied appropriately mathematical model for the curd-firming process over time $(\mathrm{CFt})$ using data measured by CRM, with the aim of summarizing all available information to yield more informative parameters respect to the traditional MCP traits. The model tested was:

$C F t=C F p *\left[1-e^{k_{C F} *(t-R C T)}\right]$

Where $\mathrm{CF}_{\mathrm{p}}(\mathrm{mm})$ is the potential asymptotical $\mathrm{CF}$ at an infinite time, $k_{\mathrm{CF}}\left(\mathrm{min}^{-1}\right)$ is the curd firming rate constant, and RCT is measured in minutes. The model offers a very good fit of data obtained from milk samples produced by cows of different breeds, ages, DIM, and reared on different farms, and the $\mathrm{k} 20$ can be estimated also for samples with very late coagulation time or with very slow curd-firming rate. Thus, for milk which have slowly coagulating samples, this model appears to be appropriate (BITTANTE, 2011). Later BITTANTE et al. (2013) proposed new equation using the 4-parameter for modeling an extended observation of $\mathrm{CF}$ that was derived by the 3-parameter equation (BITTANTE, 2011). The 4-parameter model is given as follows: $C F t=C F p *\left[1-e^{K_{C F} *(t-R C T)}\right] * e^{K_{S R} *(t-R C T)}$

Where the new parameter $\mathrm{K}_{\mathrm{SR}}$ is the curd syneresis rate constant $\left(\mathrm{min}^{-1}\right)$, and RCTeq, the rennet coagulation time (min). According to the authors, this model uses all available information to estimate the 4 parameters; these are not single-point measurements and they are; therefore, less interdependent than the traditional MCP. STOCCO et al. (2015) reported that modeling of $\mathrm{CF}$ can be useful in representing cheesemaking and understanding the effects of procedure modifications. So the MCP are important for the dairy industry; they provide important information regarding milk quality, 




cheese processing and cheese yield. The application of IAC index, for example, could be adopted as a global measure of MCP to reward producers in payment systems (PENASA et al., 2015). This method is excellent, but is not suitable for a great population level, so indirect prediction, like the mid-infrared spectral analysis of milk, seems to be a good option.

\section{Near-infrared (NIR)}

The measurements performed by the Optigraph (OPT, Ysebaert, Frépillon, France) are not based on a rheological method, but from the reading of an optical signal in the wavelength of near-infrared. Pendulums submerged in the milk samples used for the lactodynamographic analysis were replaced by sensors that record absorbance at a single wavelength in nearinfrared (NIR) of a sample, during induced coagulation by heating and addition of rennet (KÜBARSEPP et al., 2005a). During coagulation, the light emitted through milk gradually weakens as a function of changes in the structure of the micelle casein. OPT calculates the coagulation parameters (clotting time, curd firmness and the speed of aggregation) by means of certain characteristic points extracted from the optical information (UNITY SCIENTIFIC, 2009), and the optical values are then processed to simulate traditional parameters. Because of the different scales used by OPT the curd firmness value from the optical signal (volts) is transformed into values for a30 $(\mathrm{mm})$ using a calibration equation (KÜBARSEPP et al., 2005a) to obtain data comparable with the same unit. Each analysis is performed with a $10 \mathrm{~mL}$ of milk volume. However, the data obtained by the OPT are still somewhat irregular. In short, using this type of instrument is promising, but an improvement is necessary in terms of repeatability and practical significance (BITTANTE et al., 2012).

\section{Mid-infrared (MIR)}

The mid-infrared spectroscopy (MIR) involves measuring the absorption intensity of a sampleat wavelengths in the spectral range from 4000 to $200 \mathrm{~cm}^{-1}$. Most countries use this technique in official analysis to determine levels of protein, casein, fat, lactose, urea (DE MARCHI, 2014) and it has also been proposed for major fatty acids (RUTTEN et al., 2009) and mineral composition (SOYEURT et al., 2009). Wave lengths between 1550 and $1570 \mathrm{~cm}^{-1}$ are associated with proteins absorption (ETZION et al., 2004); from 2800 to $3000 \mathrm{~cm}^{-1}$ and from 1805 to $1736 \mathrm{~cm}^{-1}$ with lipids absorption (COATES, 2000). When matter is crossed by electromagnetic radiation, bonds of molecules make movements such as vibration and rotation and this contributes a certain absorption of the provided energy. On the basis of supplied energy and the amount absorbed by the irradiated sample, it is possible to determine its chemical composition (DE MARCHI et al., 2014), and with the introduction of Fourier transform infrared (FT-MIR) technology in combination with appropriate statistical procedures like least square, principal component regression or partial least squares it is possible to obtain more detailed information on milk composition (AGNET, 1998). This technology provides a low cost analysis, high output, and possibilities of application at a large scale. MIR spectroscopy can also be applied as an indirect method for MCP determining without the need to induce milk coagulation, using appropriate calibration algorithm 
(DAL ZOTTO et al., 2008). Equipment cited in the literature are MilkoScan FT 120 and FT Milko-Scan 6000 (Fourier transform infrared spectroscopy - FTIR) from Foss Electric (Denmark), using the spectral range from 4000 to $900 \mathrm{~cm}^{-1}$, and sample volume of $0.25 \mathrm{~mL}$ (BONFATTI et al., 2011b). Calibration combines MIRS values with reference traits, for example MCP. DAL ZOTTO et al. (2008) reported that $\mathrm{r}$ (min) values to fresh milk and refrigerated milk could be provided, with reproducibility coefficients of $93.5 \%$ and $64.6 \%$ for $\mathrm{r}(\mathrm{min})$ and $\mathrm{a} 30$, respectively. DE MARCHI et al. (2009) wrote MIRS like potential application, using as reference, values obtained by means of a "Computerized Renneting Meter" to determine MCP, titratable acidity and $\mathrm{pH}$ in Brown Swiss cows by the combination of different spectra in the MIRS region and the average correlation coefficient was 0.62 for $r$ (min). Linear regression graph of the measured and predicted values shows a high degree of dispersion, which suggests that the model proposed in the study was not accurate enough, but shows MIRS like potential applications for non-destructive measurements and the value of $\mathrm{r}$ (min). DE MARCHI et al. (2013) developed a calibration model for predicting r, k20 and a30 and curd firmness after 60 minutes of rennet addition using a Formagraph as the reference instrument. In fact, the lactodynamographic parameters have been chosen as method standard to develop mid-infrared spectroscopy (MIRS) prediction models (PENASA et al., 2015). Although, the predictive value remains only moderate, MIR could be used as a tool to evaluate MCP in a larger population of animals and to contribute to studies of genetic improvement. Some studies have already been conducted with animals that show good results for the MCP for selection of breeds with greater potential with respect to this parameter (CASSANDRO et al., 2008). ESKILDSEN et al. (2016) showed that concentrations of protein fractions, as well as coagulation properties, were predicted by applying calibrating partial least squares (PLS) to FTIR measurements of milk samples with coefficients of determination between 0.66 and 0.71 , respectively. The authors reported that the successful predictions of protein fractions and properties were based on indirect relationships with the total protein content, but that calibration models may not be valid for samples of a different nature. They concluded that applying FTIR based estimates of the protein fractions and coagulation properties for breeding purposes should account for these indirect relationships. However, according to STOCCO et al. (2015), in order to use it to monitor the production chain at the dairy industry level, further research is required with specific calibrations based on FTIR spectroscopy.

\section{CONCLUSION}

The cheese market is growing in several parts of the world, thus milk clotting and protein composition, especially for the genetic variants of қ-casein, and also milk acidity are important traits for the dairy industry. With this perspective the milk coagulation properties (MCP) are important, since they have a positive impact on cheese yield and could be used as indicators of production efficiency and for milk payment systems. The MCP can be determined by lactodynamographic parameters: rennet coagulation time (RCT, min) and curd firmness (a30, mm), using a Lattodinamografo ${ }^{\circledR}$, and are considered as an excellent overall evaluation criterion for milk clotting. Moreover, these parameters can be determined by near-infrared (NIR) spectroscopy, which is a promising technique, and also by mid-infrared spectroscopy (MIRS), which have a greater potential to predict the MCP, and could provide faster results for milk quality control at lower cost.

\section{REFERENCES}

ABEYKOON, C.D. et al. Milk coagulation properties and milk protein genetic variants of three cattle breeds/types in Sri Lanka. Procedia Food Science, v.6, 348-351, 2016. Available from: $<$ http:// www.sciencedirect.com/science/article/pii/S2211601X16000717>. Accessed: Feb. 16, 2017. doi: 10.1016/j.profoo.2016.02.070.

AGNET, Y. Fourier transform infrared spectrometry: a new concept for milk and milk product analysis. Brussels: Bulletin of the International Dairy Federation, 1998, 61p. (Boletim Técnico, 332).

ANNIBALDI, S. et al. Nuovi orientamenti nella valutazione tecnica del latte: tipizzazione lattodinamografica. Scienza e Tecnica Lattiero-Casearia, v.2, n.28, p.115-126, 1977.

BITTANTE, G. Modeling rennet coagulation time and curd firmness of milk. Journal of Dairy Science, v.94, p.5821-5832, 2011. Available from: <http://www.sciencedirect.com/science/journal/00220302/94/12>. Accessed: Fev. 12, 2015. doi:10.3168/jds.2011-4514.

BITTANTE, G. et al. Invited review: Genetics and modeling of milk coagulation properties. Journal of Dairy Science, v.95, p.6843-6870, 2012. Available from: <http://www.science direct. com/science/journal/00220302/95/12>. Accessed: Mar. 17, 2015. doi:10.3168/jds.2012-5507.

BITTANTE, G. et al. Prolonged observation and modelling of milk coagulation, curd firming, and syneresis. International Dairy Journal, v.29, p.115-123, 2013. Available from: <http:// www.sciencedirect.com/science/article/pii/S0958694612002361>. Accessed: Jun. 10, 2015.

BONFATTI, V. et al. Validation of a new reversed-phase highperformance liquid chromatography method for separation and quantification of bovine milk protein genetic variants. Journal of Chromatography A, v.1195, p.101-106, 2008. Available from: <http://www.sciencedirect.com/science/journal/00219673/1195/1-2>. Accessed: Jun. 02, 2015. doi: 10.1016/j.chroma.2008.04.075. 
BONFATTI, V. et al. Genetic analysis of detailed milk protein composition and coagulation properties in Simmental cattle. Journal of Dairy Science, v.94, p.5183-5193, 2011a. Available from: <http:// www.sciencedirect.com/science/journal/00220302/94/10>. Accessed: Jun. 05, 2015. doi: 10.3168/jds.2011-4297.

BONFATTI, V. et al. Effectiveness of mid-infrared spectroscopy for the prediction of detailed protein composition and contents of protein genetic variants of individual milk ofSimmental cows. Journal of Dairy Science, v.94, p.5776-5785, 2011b. Available from: $<$ http://www.sciencedirect.com/science/journal/00220302/94/12>. Accessed: Jun. 10, 2015. doi: 10.3168/jds.2011-4401.

BONIZZI, I. et al. Quantification of bovine casein fractions by direct chromatographic analysis of milk. Approaching the application to a real production context. Journal of Chromatography, v.1216, p.165-168, 2009. Available from: <http://www.sciencedirect.com/ science/article/pii/S0021967308020268>. Accessed: Mar. 03, 2015. doi: 10.101 6/j.chroma. 2008.11.045.

BYNUM, D.G.; OLSON, N.F. Influence of curd firmness at cutting on Cheddar cheese yield and recovery of milk constituents. Journal of Dairy Science, v.65, p.2281-2290, 1982. Available from: $<$ http://www.sciencedirect.com/science/journal/00220302/65/12>. Accessed: Mar. 10, 2015. doi: 10.3168/jds.S0022-0302(82)82498-3.

CASSANDRO, M. et al. Genetic parameter of milk coagulation properties and their relationships with milk yield and quality traits in Italian Holstein cows. Journal of Dairy Science, v.91, p.371-376, 2008. Available from: $<$ http://www.sciencedirect.com/science/arti cle/pii/S0022030208714735>. Accessed: May. 12, 2015. doi: 10.3168/jds.2007-0308.

CIPOLAT, C. et al. Comparison between mechanical and nearinfrared methods for assessing coagulation properties of bovine milk. Journal of Dairy Science, v.95, p.6806-6819, 2012 Available from: <http:/www.sciencedirect.com/science/article/ pii/S0022030212006935>. Accessed: Fev. 17, 2015. doi: $10.3168 /$ jds.2012-5551.

COATES, J. Interpretation of infrared spectra, a practical approach. Encyclopedia of Analytical Chemistry, v.1 p.1-23, 2000. Available from: $<$ http://matematicas.udea.edu.co/ carlopez/ftir_interpr_encilopedia_anal. pdf $>$. Accessed: Fev. 12, 2015. doi: 10.1002/97 80470027318.a560 $\overline{6}$.

DADOUSIS, C. et al. Genome-wide association of coagulation properties, curd firmness modeling, protein percentage, and acidity in milk from Brown Swiss cows. Journal of Dairy Science, v.99, p.113, 2016. Available from: <http://www.sciencedirect.com/science/ article /pii/S0022030216300091>. Accessed: Oct. 14, 2016. doi: $10.3168 /$ jds.2015-10078.

DAL ZOTTO, R. et al. Reproducibility and repeatability of measures of milk coagulation properties and predictive ability of mid-infrared reflectance spectroscopy. Journal of Dairy Science, v.91, p.4103-4112, 2008. Available from: $<\mathrm{http}: /$ www.sciencedirect.com/science /article/ pii/S0022030208710427>. Accessed: Jan. 15, 2016. doi:10.3168/ jds.2007-0772.

DEL PRATO, O.S. Trattato di tecnologia casearia. Itália: Edagricole, 2001. 1070p.

DE MARCHI, M. et al. Prediction of coagulation properties, titratable acidity and $\mathrm{pH}$ of bovine milk using MIR spectroscopy. Journal of Dairy Science, v.92, p.423-432, 2009. Available from: <http:// www.sciencedirect.com/science/article/pii/S0022030209703467>. Accessed: Jun. 02, 2015. doi: 10.3168/jds.2008-1163.
DE MARCHI, M. et al. Prediction of coagulating and noncoagulating milk samples using mid-infrared spectroscopy. Journal of Dairy Science, v.96, p.1-9, 2013. Available from: $<$ http://www.sciencedirect. com/science/article/pii/S0022030213003135>. Accessed: May. 22, 2015. doi:10.3168/jds.2012-6506.

DE MARCHI, M. et al. Invited review: mid-infrared spectroscopy as phenotyping tool for milk traits. Journal of Dairy Science, v.97, p.1171-1186, 2014. Available from: <http:// www.sciencedirect. com/science/article/pii/S0022030214000253>. Accessed: Sep. 12, 2015. doi: 10.3168/jds.2013-6799.

DI STASIO, L.; MARIANI, P. The role of protein polymorphism in the genetic improvement of milk production. Zootecnica e Nutrizione Animale, v.26, n.3, p.69-90, 2000. Available from: $<$ https://www.cabdirect.org/cabdirect/abstract/20000405647>. Accessed: May. 25, 20 15. ISSN: 0390-0487.

ESKILDSEN, C.E. et al. Quantification of bovine milk protein composition and coagulation properties using infrared spectroscopy and chemometrics: a result of collinearity among reference variables. Journal of Dairy Science, v.99, p.1-9, 2016.Available from: <http:// www.sciencedirect.com/science/article/pii/S0022030216305343>. Accessed: Nov. 24, 2016. doi: 10.3168/jds.2015-10840.

ETZION, Y. et al. Determination of protein concentration in raw milk by mid-infrared Fourier transform infrared/attenuated total reflectance spectroscopy. Journal of Dairy Science, v.87, p.2779-2788, 2004. Available from: <http://www.sciencedirect.com/Science/article/pii/ S00 22030204734050>. Accessed: May. 12, 2015. doi: 10.3168 /jds .S0022-0302(04)73405-0.

FARRELL, JR. et al. Nomenclature of the proteins of cows' milksixth revision. Journal of Dairy Science, v.87, p.1641-1674, 2004. Available from: <http://www.sciencedirect.com/ science/article/pii/ S0022030204733196>. Accessed: Jun. 07, 2015. doi: 10.3168/jds. S0022-0302(04)73319-6.

FORMAGGIONI, P. et al. Milk with abnormal acidity. VI. The role of phosphorus content and the rennet-coagulation properties of Italian Friesian herd milks. Parma, Italia, v.21, n.5, p.261-268, 2001. Annali della Facoltà di Medicina Veterinaria di Parma, 2001.

GRAML, R.; PIRCHNER, F. Effects of milk protein loci on content of their proteins. Archivfür Tierzucht, v.46, n.4, p.331-340, 2003. Available from: <http://www.archani mbreed.com/pdf/2003/ at03p331.pdf $>$. Accessed: Sep. 05, 2015.

HALLÉN, E. et al. Effect of $\beta$-casein, к-casein and $\beta$-lactoglobulin genotypes on concentration of milk protein variants. Journal Animal Breeding Genetics, v.125, p.119-129, 2008. Available from: <http:// onlinelibrary.wiley.com/doi/10.1111/jbg.2008.125.issue-2/issuetoc $>$. Accessed: May. 12, 2015. doi: 10.1111/j.1439-0388.2007.00706.x.

HILL, J.P. The relationship between beta-lactoglobulin phenotypes and milk composition in New Zealand dairy cattle. Journal of Dairy Science, v.76, n.1, p.281-286, 1993. Available from: <http:// www.sciencedirect.com/science/article/pii/S0022030293773476>. Accessed: Jun. 28, 2015. doi: 10.3168/jds.S0022-0302(93)77347-6.

IKONEN, T. et al. Genetic and phenotypic correlations between milk coagulation properties, milk production traits, somatic cell count, casein content, and $\mathrm{pH}$ of milk. Journal of Dairy Science, v.87, p.458-467, 2004.Available from: <http://www.sciencedirect.com/ science/articl e/pii/S0022030204731859>. Accessed: May. 18, 2015. doi: 10.3168/jds.S0022-0302(04)73 185-9. 
JENSEN, H.B. et al. Milk protein genetic variants and isoforms identified in bovine milk representing extremes in coagulation properties. Journal of Dairy Science, v.95, p.2891-2903, 2012. Available from: <http:// www.sciencedirect.com/science/article/pii/S0022030 212002652>. Accessed: Fev. 22, 2015. doi: 10.3168/jds.2012-5346.

KÜBARSEPP, I. et al. A comparison of the methods for determination of the rennet coagulation properties of milk. Acta Agriculturae Scandinavica, v.55, p.145-148, 2005a. Available from: <http:// www.tandfonline.com/doi/full/10.1080/09064700500453377>. Accessed: Jan. 25, 2015. doi: 10.1080/09064700500453377.

KÜBARSEPP, I. et al. Effect of $\kappa$-casein and $\beta$-lactoglobulin genotypes on the milk rennet coagulation properties. Agronomic Research, v.3, p.55-64, 2005b. Available from: <http://agronomy.emu.ee/category/ volume-03/number-1-volume-3/>. Accessed: Jan.21, 2015.

MARIANI, P. Polimorfismo delle proteine ed attitudine tecnologico-casearia del latte. La Razza Bruna Italiana, v.1, p.17, 1999. Available from: <https://www.yumpu.com/it/document/ view/36411870/polimorfismo-delle-proteine-ed-attitudinetecnologico-test-kappa>. Accessed: Fev. 27, 2015.

MARIANI, P. et al. La qualità casearia del latte di differenti razze bovine. La Razza Bruna n.1, p.7-13, 2002. Available from: < http:// www.anisn.it/workgroup/progetto\%20biodiversita/materiali\%20 didattici\%20secondo\%20ciclo_2011/CATANIA_21MARZO2011/ Filiere\%20zootecniche/La\%20qualita\%20casearia\%20Mariani. pdf>. Accessed: Fev. 10, 2015.

MAYER, H. K. et al. Composite milk protein phenotypes in relation to composition and cheese making properties of milk. International Dairy of Journal, v.7, p.305-310, 1997. Available from: <http://www. sciencedirect.com/science/article/pii/S0958694697000198>. Accessed: Jun. 04, 2015. doi: 10.1016/S0958-6946(97)00019-8.

NÁJERA, A.I. et al. Effects of $\mathrm{pH}$, temperature, $\mathrm{CaCl} 2$ and enzyme on the rennet clotting properties of milk: a multifactorial study. Food Chemistry, v.80, p.345-352, 2003. Available from: <http:// www.sciencedirect.com/science/article/pii/S0308814602002704>. Accessed: Fev. 12, 2015. doi:10.1016/S0308-8146(02)00270-4.

O'CALLAGHAN, D.J. et al. Review of systems for monitoring curd setting during cheesemaking. International Journal of Dairy Technology, v.55, p.65-74, 2002. Available from: $<$ http://onlinelibrary. wiley.com/doi/10.1111/idt.2002.55.issue-2/issuetoc >. Accessed: May. 07, 2015. doi: 10.1046/j.1471-0307.2002.00043.x.

OECD-FAO. OECD-FAO agricultural outlook. Available from: $<$ http:// www.oecd.org/site/ oecdfaoagriculturaloutlook $>$. Accessed Aug 08, 2013.

PATERSON, G.R. et al. Influence of қ-casein and $\beta$-lactoglobulin phenotype on the heat stability of milk. International Dairy of
Journal, v.9, n.3, p.375-376, 1999. Available from: <http://www. sciencedirect.com/science/article/pii/S0958694699000941>. Accessed: Jun. 17, 2015. doi: 10.1016/S0958-6946(99)00094-1.

PENASA, M. et al. Short communication: Influence of composite casein genotypes on additive genetic variation of milk production traits and coagulation properties in Holstein-Friesian cows. Journal of Dairy Science, v.93, p.3346-3349, 2010. Available from: <http:// www.sciencedirect.com/science/article/pii/S0022030210003437>. Accessed: Jun. 01, 2015. doi:10.3168/jds.2010-3164.

PENASA,M. etal.Reproducibility and repeatability of milk coagulation properties predicted by mid-infrared spectroscopy. International Dairy Journal, v.47, p.1-5, 2015. Available from: <http://www. sciencedirect.com/science/article/pii/S095869461500045X>. Accessed: Jul.2015. doi: 10.1016/j.idairyj.2015.02.004.

RUTTEN, M.J.M. et al. Predicting bovine milk fat composition using infrared spectroscopy based on milk samples collected in winter and summer. Journal of Dairy Science, v.92, p.62 02-6209, 2009. Available from: <http://www.sciencedirect.com/science/ article/pii/S0022030 209713396>. Accessed: Jan. 25, 2015. doi:10.3168/jds.2009-2456.

SOYEURT, H. et al. Potential estimation of major mineral contents in cow milk using mid-infrared spectrometry. Journal of Dairy Science, v.92, p.2444-2454, 2009. Available from: <http://www. sciencedirect.com/science/article/pii/S0022030209705594>. Accessed: Jun. 16, 2015. doi:10.3168/jds.2008-1734.

STOCCO, G. et al. Milk skimming, heating, acidification, lysozyme, and rennet affect the pattern, and predictability of milk coagulation properties and of curd-firming model parameters: a case study of Grana Padano. Journal of Dairy Science, v.98, p.1-16, 2015.Available from: <http:// www.sciencedirect.com/science/article/pii/S0022030215003756>. Accessed: Nov. 14, 2015. doi: 10.3168/jds.2014-9146.

SUMMER, A. et al. Structural and functional characteristics of Modenese cow milk in Parmigiano-Reggiano cheese production. Parma, Italia, v.22, p.163-174, 2002. Annali della Facoltà di Medicina Veterinari di Parma, 2002.

UNITY SCIENTIFIC. Optigraph, 2009. Online. Available from: $<$ http:// www.unityscientific.com/products/dairy-analysis/optigraph. asp>. Accessed: Oct. 06, 2013.

ZANNONI, M.; ANNIBALDI, S. Standardization of the renneting ability of milk by Formagraph. Scienza e Tecnica LattieroCasearia, v.32, p.79-94, 1981.

WALSTRA, P. The syneresis of curd. In: FOX, P.F. (Ed.). Cheese: chemistry, physics and microbiology. 2.ed. General aspects. London: Chapman and Hall, 1993. v.1, p.141-191. 